\title{
Salivary biomarkers and their applicability in forensic identification
}

\author{
Mithun Rajshekar, Marc Tennant* and Thejaswini BDS** \\ Menzies Research Institute, Tasmania, *Centre for Rural and \\ Remote Oral Health, University of Western Australia and **New Town, Tasmania.
}

\begin{abstract}
The constant advancement of forensic analyses has evolved into a snowball with new questions arising and solutions being looked for everyday. Forensic odontology has come a long way in understanding bite marks, its mechanism and other related factors. In general, bitemark analysis is more than often centralized on imprints of teeth on skin or food substances. What we need to understand is not all the time an entire set of dental marks is available for analysis. An adjuvant is essential to heighten the analysis and arrive at a more convincing result with a scientific backing. Saliva is an integral part of any oral cavity and is the principal focus of this paper. We intend to understand salivary manifestations of diseases and advocate the use of human saliva to identify diseases that may lead us to the suspect in cases involving bite mark analysis.
\end{abstract}

\section{INTRODUCTION}

Forensic analysis has extended into several disciplines including, but not limited to, odontology, chemistry, anthropology, microscopy and so forth. Identification of trace body fluids at a crime scene is paramount in forensic investigations. Body fluids like saliva, blood, semen can be important to criminal investigations and the information derived from them may aid in successful resolution of judicial processes. Saliva as an evidence material is not found very often but may be important in various types of abuse cases. It can be found on skin surfaces, food materials and envelopes amongst many others ${ }^{2}$

\section{BACKGROUND}

Bitemark evidence plays an important role in criminal cases involving abuse and has been used as evidence in court. Bites could originate from either the victim or the perpetrator as a mode of defense or as intent to cause injury by the perpetrator respectively. Either way they could contain forensic information ${ }^{3}$ Bitemarks on skin normally contain several forms of injuries but most of them also have some contact of the soft tissues. ${ }^{4}$ During the process of contact between teeth and skin, the contact of soft tissues result in conveyance of traces of saliva which may be collected during post examination of the bite mark by swabbing the area around the bitemark. This sample would then be compared to a sample from the suspect. This is possible when the suspect is known and a sample from him is obtained. The hypothesis behind this manuscript is "what if the suspect is unknown, What if all we have is a saliva sample with no dental markers enough to identify the perpetrator? Would we be able to isolate salivary markers found in diseases and try and match them with people know to have that condition to arrive at a positive identification of the suspect? The aim of this review is to shed some light on various manifestations of diseases on the oral cavity and advocate the use of human saliva to identify diseases that may lead us to the suspect in cases involving bite marks.

\section{SALIVA}

Saliva is a product of the pairs of major salivary glands and several minor salivary glands present in the oral cavity and the buccal cheeks. ${ }^{5}$ Saliva is primarily composed of water, enzymes, proteins, electrolytes, mucins and nitrogenous products. ${ }^{6}$

Saliva is derived from salivary glands present below the oral mucosa. A normal human secretes about $600 \mathrm{~mL}$ of saliva everyday. This saliva is rich in minerals, electrolytes, buffers, enzymes and enzyme inhibitors, growth factors and cytokines, immunoglobulin's (e.g., secretory immunoglobulin A), mucins and other glycoproteins. ${ }^{7}$ Once saliva enters the oral cavity making its way through the salivary ducts, it coalesces with blood cells, micro-organisms of the oral cavity, food and upper airway secretions. This 
mixture may contain vital information about the quality of life, health and general wellbeing of a person. ${ }^{8}$

In general, saliva helps us in eating, swallowing and also everyday activities like speaking. It helps keep the oral cavity hydrated, hence protecting teeth from microorganisms. ${ }^{8,9}$ Along with dental caries detection, scientists have been pursuing interest in identifying salivary biomarkers that can be used to identify diseases and therefore monitor general health of people and detect diseases such as AIDS ,diabetes, Sjögren's syndrome, alcoholic cirrhosis, cystic fibrosis, diseases of the adrenal cortex, cardiovascular diseases, and ${ }^{10}$ in the early stage of onset. ${ }^{6}$

The advantages of using saliva over blood have been attributed to its ease of access (except in cases of xerostomia), low costs in acquiring samples and ease of handling (in people with homophobia) and its non invasive collection techniques. The presence of protein and its components and its comparisons in healthy population have been advocated as a possible method of bio-marking as saliva of individuals with diseases may carry certain proteins specific to certain diseases. ${ }^{6}$

\section{SALIVARY FLORA AND FAUNA:}

The oral cavity is made up of a large quantity and wide variety of bacteria. Some micro-organisms commonly found in the oral cavity are streptococcus salivarius that belong to the Viridans group of streptococci and can supposedly be identified by colony morphology on Mitis Salivarius on agar plates. ${ }^{11}$ More than often saliva is contaminated by the bacteria present in the oral cavity. If this saliva is transferred on to the skin, and it has salivary markers along with the normal constituents of saliva, then it is possible to identify a suspect based on that information. ${ }^{4}$ These salivary contents could also transfer on to the micro openings formed on the skin during biting and hence could result in an infection. Brown et al (1983) tried to understand the possibility of fingerprinting bacteria present in saliva to be used as an assistance in bite mark cases when saliva has been left on the skin for prolonged periods and still could be recovered and information collected from it. ${ }^{4}$

\section{OTHER PHYSICAL CONDITIONS CONTRIBUTING TO ORAL CHANGES:}

Vitamin K deficiency: Vitamin K is an important factor that aids in the production of procoagulant factors II, VII,IX and X along with anticoagulant factors like Protein $\mathrm{C}$ and Protein S. Oral manifestations of vitamin $\mathrm{K}$ deficiency leads to submucosal haemorrhage along with gingival bleeding. ${ }^{12}$

Langerhans cell Histiocytosis: Langerhans Cell Histiocytosis is primarily manifested orally with irregular ulcerations of the hard palate along with ulcerated nodules and inflamed gingival leading to halitosis and discomfort on chewing. Larger lesions may result in exposure of underlying bone with ecchymosis and periodontitis sometimes leading to more severe necrotising gingivitis. Radiographically the teeth may have a hallmark "floating in the air" appearance. ${ }^{12,13}$

Hypoparathyroidism: Decreased secretion of the parathyroid hormone normally occurs as a result of surgical remotion of the parathyroid glands. This is because of autoimmune destruction of the parathyroid glands pointing fingers towards rare syndromes like DiGeorge syndrome. Oral manifestations of this condition are presence of pitting enamel hypoplasia and sometimes failure of eruption of teeth. ${ }^{12}$

Mucopolysaccharidosis:Mucopolysaccharidoss is a metabolic disorder caused due to absence or malfunctioning of lysosomal enzymes. Oral manifestations of this disease are macroglossia, gingival hyperplasia of the anterior region of the oral cavity along with several supernumerary teeth and thinning of enamel with pointed cusp tips can be noted. ${ }^{14}$

Kawasaki disease: Kawasaki disease is an autoimmune disease with classic features of edema or erythema of the extremeties, polymorphous exathem, bilateral conjunctival injection, redness of tongue with associated strawberry shaped formations on tongue and acute lymphadenopathy. ${ }^{12}$

Wegener granulomatosis: Wegeners granulomatosis is a vascular disorder and most often indicates an oncoming renal condition. ${ }^{15}$ Oral features seen in this disease are the characteristic "strawberry gingivitis" along with 
mobile teeth associated with the destruction of the underlying bone. Less commonly, features like the presence of an oro-antral fistula may be seen. ${ }^{16}$

Scleroderma: Scleroderma is a chronic autoimmune disorder having variable oral manifestations. They may be microstomia, xerostomia, loss of mobility of the tongue, widened periodontal ligament spaces and resorption of ramus, coronoid process, chin and condyles can be seen on radiographs. ${ }^{12}$ Saliva has been extensively used in detection and diagnosis of oral diseases, but its use as a marker for systemic diseases has been advocated for sometime now. ${ }^{17}$ Tables 1 and 2 show probable factors influencing salivary flow/composition and probable salivary predictors for systemic diseases respectively.

\section{DISCUSSION}

Saliva constitutes DNA, RNA, proteins and bacteria that may be of interest to the forensic community because of its capacity to carry vital information. ${ }^{18,19}$ Research has demonstrated that there is evident variability in salivary transcriptase profiles between patients suffering from pancreatic cancer and normal healthy controls and may be used in the detection of pancreatic cancer. ${ }^{20}$

Currently, researchers have developed salivary markers to detect and diagnose oral cancer employing proteomic, genomic, miRNA and other metabolic techniques. The proteomic and genomic salivary markers have been validated by a group of investigators from the National Cancer Institutes Early Detection Research Network in the Indian and the Serbian populations and the markers are ready for academic validation in the near future. ${ }^{17}$

Salivary markers have also been tested for their ability to detect breast cancer in concurrence with mammography. c-erbB-2 is a prognostic proteome proposed for use in detection and identification of malignant tumours in women. ${ }^{6}$

\section{CONCLUSION}

Systemic diseases are known to manifest irregularities in the head and neck region and the oral cavity in particular. Advanced clinical research in identifying saliva markers that may be used in the identification of diseases is strongly recommended. This would enable wider use of saliva and at some stage may even replace invasive methods of collection of specimen used in detecting and diagnosing diseases. Apart from acting as a diagnostic tool, saliva biomarkers may also be used in forensics, not only in cases involving bitemarks but also in general identification of people and in situations of mass disasters. By matching salivary biomarkers for any particular disease and tracking that disease to hospital visits and hence arriving at a positive identification, these biomarkers may be used to identify people who's DNA are not on any database.

Identifying salivary biomarkers that may be used in detecting and diagnosing systemic diseases based on the relativity between a specific disease and salivary protein changes seen shall surely provide a head start in fighting the disease, but may also provide vital information in identifying a person involved in crime.

It is not always necessary that a person had his/her disease tested and is a known patient, but this method would surely act as a positive reinforcement in the identification process where every bit of information is important and time saving. 
Table 1: Probable factors influencing salivary flow/composition

\begin{tabular}{|c|l|}
\hline Salivary flow index: & $\begin{array}{l}\text { The primary agent controlling composition of saliva is the } \\
\text { salivary flow index. This mainly depends on the type, intensity } \\
\text { and the duration of the stimulus. This increased salivary flow } \\
\text { index results in increased levels of sodium, proteins, calcium, } \\
\text { chloride and bicarbonates and decreased levels of phosphates } \\
\text { and magnesium. This knowledge may be used as marker in } \\
\text { saliva and therefore be used in forensic situations. 22 }\end{array}$ \\
\hline Medications & $\begin{array}{l}\text { Anticholinergic drugs like antidepressants, anxiolytics, } \\
\text { antihypertensives or antihistamines may reduce the salivary } \\
\text { flow therefore changing the salivary composition. Presence or } \\
\text { absence of normal salivary constituents can be looked up in } \\
\text { cases involving bitemarks where a saliva sample can be } \\
\text { obtained. 22 }\end{array}$ \\
\hline Alcohol & $\begin{array}{l}\text { Extensive consumption of alcohol leads to ethanol overdose } \\
\text { directly affecting the salivary flow due to the modified release } \\
\text { of proteins and amylase and a decreased output of } \\
\text { electrolytes. } 22\end{array}$ \\
\hline
\end{tabular}


Table 2: Probable salivary predictors for systemic diseases.

\begin{tabular}{|c|c|c|c|}
\hline Condition & $\begin{array}{l}\text { Geographic } \\
\text { Preponderance }\end{array}$ & Oral manifestations & $\begin{array}{l}\text { Salivary changes } \\
\text { (Present or } \\
\text { Possible) }\end{array}$ \\
\hline $\begin{array}{l}\text { Pernicious } \\
\text { Anaemia }\end{array}$ & $\begin{array}{l}\text { African } \\
\text { American and } \\
\text { Hispanic } \\
\text { populations in } \\
\text { America }\end{array}$ & $\begin{array}{l}\text { Burning of tongue, lips and } \\
\text { other mu cosal sites of the } \\
\text { oral cavity associated with } \\
\text { atrophy of tongue clinically } \\
\text { presented as magenta } \\
\text { tongue. }\end{array}$ & $\begin{array}{l}\text { Possible traces of } \\
\text { Vitamin B12 or } \\
\text { Cobalamin in } \\
\text { saliva? }^{12}\end{array}$ \\
\hline Leukaemia & None & $\begin{array}{l}\text { Diffuse oral candidiasis, } \\
\text { as sociated with spontaneous } \\
\text { gingival bleeding. }\end{array}$ & $\begin{array}{l}\text { Traces of oral } \\
\text { candida? }^{12}\end{array}$ \\
\hline $\begin{array}{l}\text { Multiple } \\
\text { Myeloma }\end{array}$ & None & $\begin{array}{l}\text { Well defined punched out } \\
\text { radiographic lesions in the } \\
\text { jaw. Enlarged tongue with } \\
\text { amyloid deposits on tongue. }\end{array}$ & $\begin{array}{l}\text { Presence of } \\
\text { amyloid material } \\
\text { in saliva? }\end{array}$ \\
\hline $\begin{array}{l}\text { Sjogrens } \\
\text { Syndrome }\end{array}$ & None & $\begin{array}{l}\text { Thick ropy mucinous saliva, } \\
\text { oral candidal infections and } \\
\text { presence of inflammation of } \\
\text { parotid gland leading to } \\
\text { purulent discharge. }\end{array}$ & $\begin{array}{l}\text { Evidence of } \\
\text { thickened saliva } \\
\text { and traces of } \\
\text { candida along } \\
\text { with purulent } \\
\text { discharge? }^{12}\end{array}$ \\
\hline Amyloi dosis & None & $\begin{array}{l}\text { Macroglossia and deposition } \\
\text { of amyloid protein on tongue }\end{array}$ & $\begin{array}{l}\text { Presence of } \\
\text { amyloid material } \\
\text { in saliva? }^{12}\end{array}$ \\
\hline $\begin{array}{l}\text { Diabetes } \\
\text { Mellitus }\end{array}$ & None & $\begin{array}{l}\text { Presence of periodontal } \\
\text { abscesses, oral candidiasis, } \\
\text { marked increase in salivary } \\
\text { glucose levels and crevicular } \\
\text { fluid. Fungal infections like } \\
\text { zygomycosis can be seen } \\
\text { too. }\end{array}$ & $\begin{array}{l}\text { Presence of } \\
\text { candida, high } \\
\text { glucose and } \\
\text { crevicular fluid } \\
\text { levels in saliva? }^{12}\end{array}$ \\
\hline $\begin{array}{c}\text { Systemic } \\
\text { Masto Cystosis }\end{array}$ & None & $\begin{array}{l}\text { Mast cell infiltration into the } \\
\text { salivary glands }\end{array}$ & $\begin{array}{l}\text { Evidence of } \\
\text { presence of mast } \\
\text { cells in saliva? }\end{array}$ \\
\hline $\begin{array}{l}\text { Iron deficiency } \\
\text { anaemia }\end{array}$ & None & $\begin{array}{l}\text { Angular chelitis, atrophic } \\
\text { glossitis, glossdynia and is } \\
\text { normally a predisposing } \\
\text { factor for candidiasis. }\end{array}$ & $\begin{array}{l}\text { Presence of } \\
\text { traces of candida } \\
\text { in saliva? }{ }^{21}\end{array}$ \\
\hline
\end{tabular}




\section{References}

1. Sweet, D. and D. Hildebrand, Saliva from cheese bite yields DNA profile of burglar: a case report. International journal of legal medicine, 1999;112:201-203.

2. Rousselet, F. and P. Mangin, Mitochondrial DNA polymorphisms: a study of 50 French Caucasian individuals and application to forensic casework. International journal of legal medicine, 1998;111:292-298.

3. Barbenel, J. and J. Evans, Bite marks in skin-mechanical factors. Journal of the Forensic Science Society, 1974;14:235238.

4. Brown, K., et al., The survival of oral streptococci on human skin and its implication in bite-mark investigation. Forensic Sci Int, 1984.;26:193-197.

5. Humphrey, S.P. and R.T. Williamson, $A$ review of saliva: normal composition, flow, and function. The Journal of prosthetic dentistry, 2001;85:162-169.

6. Vitorino, R., et al., Identification of human whole saliva protein components using proteomics. Proteomics, 2004;4:11091115.

7. Tabak, L.A., In defense of the oral cavity: structure, biosynthesis, and function of salivary mucins. Annual review of physiology, 1995;57:547-564.

8. Lawrence, H.P., Salivary markers of systemic disease: noninvasive diagnosis of disease and monitoring of general health. JOURNAL-CANADIAN DENTAL ASSOCIATION, 2002;68:170175.

9. Lenander-Lumikari, M. and V. Loimaranta, Saliva and dental caries. Advances in dental research, 2000;14:4047.

10. Banks, R.E., et al., Proteomics: new perspectives, new biomedical opportunities. The Lancet, 2000;356:1749-1756.

11. Sherman, J., C. Niven, and K. Smiley, Streptococcus salivarius and other nonhemolytic streptococci of the human throat. Journal of bacteriology, 1943;45:249-263.
12. Islam, N.M., I. Bhattacharyya, and D.M. Cohen, Common oral manifestations of systemic disease. Otolaryngologic Clinics of North America, 2011;44:161.

13. Madrigal-Martínez-Pereda, C., et al., Langerhans cell histiocytosis: literature review and descriptive analysis of oral manifestations. Medicina oral, patología oral y cirugía bucal, 2009;14:E222.

14. Alpöz,A.R., et al., The oral manifestations of Maroteaux-Lamy syndrome (mucopolysaccharidosis VI): a case report. Oral Surgery, Oral Medicine, Oral Pathology, Oral Radiology, and Endodontology, 2006;101:632-637.

15. Ruokonen, H., et al., "Strawberry like" gingivitis being the first sign of Wegener's granulomatosis. European Journal of Internal Medicine, 2009;20:651-653.

16. Stewart, C., et al., Oral manifestations of Wegener's granulomatosis A report of three cases and a literature review. The Journal of the American Dental Association, 2007;138(:338-348.

17. Wong, D.T., Salivaomics. The Journal of the American Dental Association, 2012;143:19S-24S.

18. Zubakov, D., et al., Stable RNA markers for identification of blood and saliva stains revealed from whole genome expression analysis of time-wise degraded samples. International journal of legal medicine, 2008;122:135-142.

19. Ballantyne, J., Validity of messenger RNA expression analyses of human saliva. Clinical cancer research, 2007;13:13501350.

20. Zhang, L., et al., Salivary transcriptomic biomarkers for detection of resectable pancreatic cancer. Gastroenterology, 2010;138:949-957. e7.

21. Schlosser, B.J., M. Pirigyi, and G.W. Mirowski, Oral Manifestations of Hematologic and Nutritional Diseases. Otolaryngologic Clinics of North America, 2011;44:183.

22. de Almeida, P.D.V., et al., Saliva composition and functions: a comprehensive review. J Contemp Dent Pract, 2008;9:72-80. 